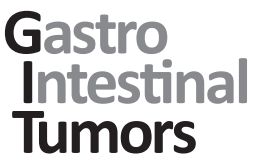

\title{
Presence of JC Polyomavirus in Nonneoplastic Inflamed Colon Mucosa and Primary and Metastatic Colorectal Cancer
}

\author{
Nadia Esmailzadeh ${ }^{a}$ Mohammad Ranaee $^{b} \quad$ Ahad Alizadeh $^{c}$ \\ Aynaz Khademiand $^{d}$ Saghar Saber Amolid Farzin Sadeghi ${ }^{\mathrm{e}}$ \\ a Department of Microbiology, Tehran Medical Sciences, Islamic Azad University, Tehran, \\ Iran; 'b Department of Pathology, School of Medicine, Babol University of Medical Sciences, \\ Babol, Iran; ' Metabolic Diseases Research Center, Qazvin University of Medical Sciences, \\ Qazvin, Iran; d Student Research Committee, School of Medicine, Babol University of

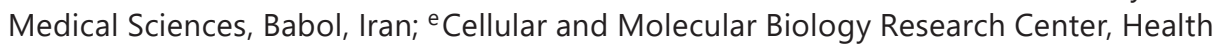 \\ Research Institute, Babol University of Medical Sciences, Babol, Iran
}

\section{Keywords}

JC polyomavirus · Large T antigen · Colorectal cancer · Viral load

\begin{abstract}
Background: Despite decades of epidemiologic and histopathologic investigations, the association between JC polyomavirus (JCPyV) infection and colorectal cancer (CRC) remains controversial. Objective: This study tested the presence of JCPyV sequences and determined the viral load in a series of colorectal samples from Iranian patients. In total, 223 formalin-fixed paraffin-embedded samples from patients diagnosed with primary and metastatic CRC as well as with nonneoplastic inflamed colon mucosa were analyzed by quantitative real-time PCR for the presence of JCPyV large tumor antigen (LT-Ag) sequences. Results: JCPyV LT-Ag sequences were detected in $18.6 \%$ of the CRC tissues and in $15.5 \%$ of the nonneoplastic control group. Viral LT-Ag was quantified in 18/100 primary colon adenocarcinomas, 2/10 metastatic adenocarcinomas, and $1 / 3$ primary adenocarcinomas of the rectum. Two JCPyV-positive metastatic tumors presented a negative test result for JCPyV in the corresponding primary tumor. The median JCPyV LT-Ag copy number was $64 \times 10^{-2}$ per cell and $14 \times 10^{-2}$ per cell in the CRC cases and the nonneoplastic samples, respectively. There was no statistically significant difference between the two study groups regarding median LT-Ag DNA load ( $p=0.059$ ). Among the JCPyV-positive samples, the LT-Ag DNA load was higher in 2 metastatic tumors (from a patient with lung metastasis: $232 \times 10^{-2}$ copies per cell; from a patient with liver me-
\end{abstract}


tastasis: $121 \times 10^{-2}$ copies per cell). Conclusions: The detection of JCPyV DNA at low copy numbers (lower than 1 viral copy per cell equivalent) and the absence of viral sequences in the corresponding primary tumors of the JCPyV-positive metastatic samples weaken the hypothesis of an etiological role of JCPyV in primary CRC induction.

(c) 2019 The Author(s)

Published by S. Karger AG, Basel

\section{Introduction}

Colorectal cancer (CRC) ranks as the third most commonly diagnosed malignancy and the second leading cause of death from cancer throughout the world [1]. The etiology of CRC is still uncertain, and many risk factors have been proposed, including genetic, lifestyle, and environmental factors [2]. In addition, the hypothesis that viral infections may be associated with the etiology of CRC has also been proposed [3]. With respect to viral etiologies of CRC, JC polyomavirus (JCPyV) has been among the most widely investigated. Infection with JCPyV is widespread, and by early adulthood, approximately $70-80 \%$ of the population is seropositive [4]. The exact route of JCPyV transmission is unknown. However, considering that JCPyV has been detected in tonsil and oropharynx tissue supports a respiratory mode of transmission [5]. In addition, since the JCPyV genome and complete virion are frequently detected in raw urban sewage, it is thought to be spread by consuming contaminated water or food [6]. JCPyV particles can remain intact at very low $\mathrm{pH}$ levels, supporting its viability in the gastrointestinal tract [7].

Several lines of evidence support the potential role of JCPyV in the development of human tumors, especially of CRC. First, JCPyV was able to transform cells in culture and to induce cancer in several experimental animals [8-10]. Second, JCPyV encodes oncoproteins that deregulate normal progression of the cell cycle, disrupt chromosomal integrity, and inactivate tumor suppressor proteins [11]. Expression of the JCPyV large tumor antigen (LT-Ag) oncoprotein has been significantly associated with chromosomal instability in a colon cancer cell line [12]. The presence of JCPyV LT-Ag sequences in CRC tissues was confirmed in several studies [13-16]. Moreover, JCPyV LT-Ag expression in CRC tissues was also demonstrated in several investigations $[14,17,18]$. In contrast, the presence of JCPyV in CRC tissues was not demonstrated in a number of other studies, and the association between JCPyV infection and CRC remains controversial [19-21].

Several investigations have provided evidence that different DNA tumor viruses may play a role in the induction of tumor cell migration and promote an invasive and metastasizing phenotype $[22,23]$. This concept was also demonstrated for JCPyV in two separate studies. First, Link et al. [24] revealed that JCPyV LT-Ag could contribute to metastasis and malignant behavior in CRC cells through increased migration and invasion. Second, Sinagra et al. [25] showed with a small sample size that the JCPyV genome is detected in both primary CRC and CRC liver metastasis. In addition, the detection of high levels of JCPyV viral load (i.e., at least a single copy of the viral genome in each cell) in tumor cells compared with nonneoplastic cells supports its possible role in colorectal carcinogenesis [26].

As mentioned above, the presence of JCPyV DNA at high copy numbers in both primary CRC and secondary (metastatic) tumors is an important aspect that strengthens the hypothesis of a pathogenic role of JCPyV in colorectal carcinogenesis. Hence, the facts reviewed above encouraged us to explore JCPyV viral load (as viral copy number per cell) in a series of colorectal samples from Iranian patients and to investigate whether JCPyV could have any association with the pathogenesis of primary and metastatic CRC. In the present study, we tested 223 formalin-fixed paraffin-embedded (FFPE) samples from Iranian patients diagnosed with primary and metastatic CRC as well as nonneoplastic inflamed colon mucosa for the presence of JCPyV sequences by quantitative real-time PCR. 


\section{Materials and Methods}

Tissue Specimens

In this cross-sectional study, a total of 223 colorectal FFPE surgical specimens, including 90 primary colon adenocarcinomas, 3 primary adenocarcinomas of the rectum, 10 pairs of primary colon adenocarcinomas and corresponding metastatic specimens from the same patients, and 110 samples of nonneoplastic inflamed colon mucosa diagnosed between 2012 and 2017, were collected from the archives of the Pathology Department at Ayatollah Rouhani Hospital affiliated to Babol University of Medical Sciences. Data related to demographic patient characteristics were retrieved from the patients' medical records. Of the 10 metastatic tumors, 6 cases were liver and lung metastases (with 3 samples each), 2 cases were brain metastases, and 2 cases were cervical and ovary metastases (with 1 sample each).

\section{DNA Extraction}

Deparaffinization of the FFPE surgical specimens was performed as described previously [27, 28]. In brief, the paraffin-embedded tissue specimens were cut into 5 - $\mu \mathrm{m}$-thick tissue slices, and 8 sections were collected in a sterile nuclease-free microcentrifuge tube. In order to avoid cross-contamination, a different microtome blade was used for each tissue block, and the cutting surface was washed with xylene and ethanol. To remove the paraffin, the FFPE sections were incubated 3 times in $500 \mu \mathrm{L}$ of xylene for $10 \mathrm{~min}$ at $60^{\circ} \mathrm{C}$ and were subsequently washed with absolute ethanol. In all cases, DNA was extracted from $25 \mathrm{mg}$ of FFPE sections using the tissue genomic DNA Extraction Mini Kit (Favorgen Biotech Corp., Changzhi, Taiwan) according to the manufacturer's instructions. Sterile microcentrifuge tubes containing only reaction mixtures were processed simultaneously with the tissue samples as an extraction negative control. The quality and quantity of purified DNA were determined using a NanoDrop spectrophotometer (Thermo Fisher Scientific, Wilmington, DE, USA). The purified DNA yield was in the range of $\sim 70-150 \mathrm{ng} /$ $\mu \mathrm{L}$, and the A260/A280 ratio was in the range of $\sim 1.8-1.9$, which showed a good quality of genomic DNA. Determination of JCPyV DNA extraction efficiency was done according to a previously described procedure [29].

\section{JCPyV Quantitative Real-Time PCR}

A TaqMan real-time PCR method was utilized to detect and measure the amount of JCPyV viral load using a Rotor-Gene ${ }^{\circledR} \mathrm{Q}$ (Qiagen GmbH, Hilden, Germany) real-time PCR system according to a previously described procedure [30]. A proven single-copy cellular RNase P gene was employed to normalize viral copies to the number of cell equivalents. Specifically, primer sets and a TaqMan probe targeting the JCPyV LT-Ag gene and the human RNase P gene were used in the real-time PCR reaction [31,32]. The construction of plasmids containing cloned target sequences of JCPyV LT-Ag and the human RNase P gene (quantitative standards for real-time PCR) was described previously [30]. Each real-time PCR reaction consisted of $100 \mathrm{ng}$ of purified DNA. To evaluate the sensitivity of quantitative real-time PCR, a standard curve was generated using a 10-fold dilution series of JCPyV LT-Ag plasmid in genomic extracts obtained from JCPyV-negative FFPE samples. Dilution experiments using purified plasmids containing a JCPyV LT-Ag amplicon revealed that quantitative real-time PCR invariably detected 50 copies of the JCPyV LT-Ag plasmid on a background of $100 \mathrm{ng}$ of genomic DNA.

\section{Statistical Analysis}

Data were analyzed using the R 3.4.1, "arm," and "ggplot2" packages. Normal distribution of variables was evaluated by the Shapiro-Wilk test. Descriptive results are presented as mean \pm standard deviation for normal quantitative variables, and as number (percent) for count data. Median and interquartile range (IQR) was used for nonparametric variables which did not have a normal distribution. The independentsample $t$ test or Mann-Whitney U test was used for comparing means or distributions of quantitative variables, as appropriate. The $\chi^{2}$ test was used for assessing associations of qualitative variables. The correlations between JCPyV positivity, JCPyV viral load with histological differentiation, and clinicopathologic stage were evaluated using Spearman's correlation. A $p$ value $\leq 0.05$ was considered to be statistically significant. 
Esmailzadeh et al.: JC Polyomavirus Sequences in Human Colorectal Cancer

Table 1. Demographic and histological characteristics of the subjects participating in the study

\begin{tabular}{|c|c|c|c|c|}
\hline Variable & $\begin{array}{l}\text { Primary and } \\
\text { metastatic CRC }\end{array}$ & $\begin{array}{l}\text { Nonneoplastic } \\
\text { inflamed colon mucosa }\end{array}$ & Total & $p$ value \\
\hline Subjects & $113(50.7 \%)$ & $110(49.3 \%)$ & 223 & - \\
\hline \multicolumn{5}{|l|}{ Age group } \\
\hline$\leq 50$ years & 97 (85.8\%) & $49(44.5 \%)$ & 146 & \multirow[t]{2}{*}{$<0.001$} \\
\hline$>50$ years & $16(14.2 \%)$ & $61(55.5 \%)$ & 77 & \\
\hline \multicolumn{5}{|l|}{ Gender } \\
\hline Male & $60(53.1 \%)$ & $54(49.1 \%)$ & 114 & \multirow[t]{2}{*}{0.593} \\
\hline Female & $53(46.9 \%)$ & $56(50.9 \%)$ & 109 & \\
\hline Mean age (range), years & $61.5 \pm 12(28-90)$ & $47.8 \pm 16(17-87)$ & $54.6 \pm 16(17-90)$ & $<0.001$ \\
\hline \multicolumn{5}{|l|}{ Smoking status } \\
\hline Smoker & $26(23.0 \%)$ & $34(30.9 \%)$ & 60 & \multirow[t]{2}{*}{0.184} \\
\hline Nonsmoker & $87(77.0 \%)$ & $76(69.1 \%)$ & 163 & \\
\hline \multicolumn{5}{|l|}{ Alcohol use } \\
\hline Yes & $13(11.5 \%)$ & $12(10.9 \%)$ & 25 & \multirow[t]{2}{*}{0.888} \\
\hline No & $100(88.5 \%)$ & $98(89.1 \%)$ & 198 & \\
\hline \multicolumn{5}{|l|}{ Family history of CRC } \\
\hline Yes & $48(42.5 \%)$ & $50(45.5 \%)$ & 98 & \multirow[t]{2}{*}{0.645} \\
\hline No & $65(57.5 \%)$ & $60(54.5 \%)$ & 125 & \\
\hline \multicolumn{5}{|l|}{ Histological differentiation } \\
\hline Well differentiated & $94(89.5 \%)$ & - & - & - \\
\hline Moderately differentiated & $7(6.7 \%)$ & - & - & - \\
\hline Poorly differentiated & $4(3.8 \%)$ & - & - & - \\
\hline
\end{tabular}

Bold type denotes significance. CRC, colorectal cancer.

\section{Results}

\section{Patient Characteristics}

All 223 enrolled subjects (mean age, $54.6 \pm 16$ years; range, $17-90)$ were divided into two groups: (1) subjects with a primary and metastatic CRC diagnosis $(n=113)$ and (2) those with nonneoplastic inflamed colon mucosa $(n=110)$. Table 1 shows the subjects' demographic characteristics and lifestyle information. The patients with primary and metastatic CRC were older than the nonneoplastic patients $(p<0.001)$. All primary and metastatic CRC samples were adenocarcinomas.

\section{Detection and Quantitation of JCPyV}

The results from JCPyV detection revealed the presence of viral LT-Ag gene in a total of $38(17 \%)$ of the 223 tested samples. JCPyV DNA was detected in FFPE specimens of 21 of the 113 primary and metastatic CRC cases $(18.6 \%)$ and 17 of the 110 nonneoplastic inflamed colon mucosa cases $(15.5 \%)$. There was no significant difference in JCPyV positivity between the two study groups $(p=0.534)$. In detail, among the 113 tested samples in the primary and metastatic CRC group, the JCPyV LT-Ag gene was detected in $18 \%(18 / 100)$ of the primary colon adenocarcinomas, $20 \%$ (2/10) of the metastatic adenocarcinomas, and 33.3\% (1/3) of the primary adenocarcinomas of the rectum. Two JCPyV-positive metastatic tumors belonged to patients with liver and lung metastasis, and both of them presented a negative test result for JCPyV in the corresponding primary tumor. Table 2 shows a summary of the clinicopathologic data on the JCPyV DNA-positive tumors.

JCPyV LT-Ag DNA load was determined as the viral copy number per cell using a proven single-copy gene, human RNase P. Amplification of this cellular gene could also be a marker 
Table 2. Summary of the clinicopathologic data on JCPyV DNA-positive tumors

\begin{tabular}{|c|c|c|c|c|c|c|c|c|c|}
\hline Case & $\begin{array}{l}\text { Age, } \\
\text { years }\end{array}$ & Gender & $\begin{array}{l}\text { Smoking } \\
\text { status }\end{array}$ & $\begin{array}{l}\text { Alcohol } \\
\text { use }\end{array}$ & $\begin{array}{l}\text { Family } \\
\text { history } \\
\text { of CRC }\end{array}$ & $\begin{array}{l}\text { Primary/ } \\
\text { metastatic }\end{array}$ & $\begin{array}{l}\text { Clinico- } \\
\text { pathologic } \\
\text { stage }\end{array}$ & $\begin{array}{l}\text { Histological } \\
\text { differentiation }\end{array}$ & $\begin{array}{l}\text { JCPyV } \\
\text { LT-Ag } \\
\text { gene }\end{array}$ \\
\hline $\mathrm{CC} 1$ & 76 & M & NS & No & Yes & Metastatic (lung) & IVA & Well differentiated & + \\
\hline CC11 & 80 & M & NS & No & No & Primary & IIA & Well differentiated & + \\
\hline $\mathrm{CC} 12$ & 62 & M & NS & Yes & Yes & Primary & IIA & Moderately differentiated & + \\
\hline $\mathrm{RC} 14$ & 51 & M & $\mathrm{S}$ & Yes & Yes & Primary (RC) & IIIB & Moderately differentiated & + \\
\hline CC18 & 85 & $\mathrm{~F}$ & NS & No & No & Primary & $\mathrm{U}$ & Well differentiated & + \\
\hline $\mathrm{CC} 22$ & 51 & M & NS & No & Yes & Primary & IIA & Moderately differentiated & + \\
\hline CC45 & 53 & $\mathrm{~F}$ & NS & No & No & Primary & $\mathrm{U}$ & Well differentiated & + \\
\hline CC49 & 57 & M & NS & No & No & Primary & $\mathrm{U}$ & Well differentiated & + \\
\hline CC55 & 59 & $\mathrm{~F}$ & NS & No & No & Primary & $\mathrm{U}$ & Well differentiated & + \\
\hline CC63 & 69 & $\mathrm{~F}$ & NS & No & No & Primary & $\mathrm{U}$ & Well differentiated & + \\
\hline CC67 & 43 & M & NS & Yes & No & Primary & IIA & Well differentiated & + \\
\hline CC73 & 90 & M & $\mathrm{S}$ & No & Yes & Primary & $\mathrm{U}$ & Well differentiated & + \\
\hline CC82 & 72 & M & S & Yes & No & Primary & $\mathrm{U}$ & Well differentiated & + \\
\hline CC83 & 82 & M & NS & No & No & Primary & $\mathrm{U}$ & Well differentiated & + \\
\hline CC84 & 63 & $\mathrm{~F}$ & NS & No & Yes & Primary & IIA & Poorly differentiated & + \\
\hline CC94 & 61 & $\mathrm{~F}$ & NS & No & No & Primary & $\mathrm{U}$ & Moderately differentiated & + \\
\hline CC95 & 55 & M & NS & No & No & Primary & $\mathrm{U}$ & Well differentiated & + \\
\hline CC103 & 53 & $\mathrm{~F}$ & NS & No & No & Primary & IIA & Well differentiated & + \\
\hline CC104 & 64 & M & $\mathrm{S}$ & No & Yes & Metastatic (liver) & IVA & Moderately differentiated & + \\
\hline CC105 & 69 & M & NS & No & No & Primary & IB & Well differentiated & + \\
\hline CC106 & 66 & $\mathrm{~F}$ & NS & No & No & Primary & $\mathrm{U}$ & Well differentiated & + \\
\hline
\end{tabular}

CC, colon cancer; RC, rectal cancer; F, female; M, Male; NS, nonsmoker; S, smoker; U, unknown; CRC, colorectal cancer; JCPyV, JC polyomavirus; LT-Ag, large tumor antigen.

Fig. 1. Median JCPyV LT-Ag DNA load (interquartile range) in the two study groups. The $p$ value was determined by the MannWhitney U test. JCPyV, JC polyomavirus; LT-Ag, large tumor antigen; CRC, colorectal cancer.

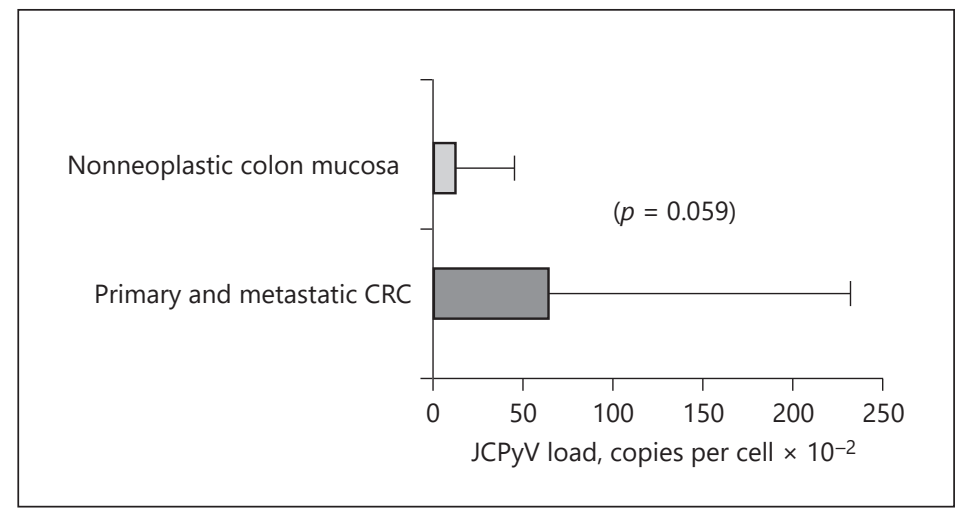

for the presence of sufficient amplifiable DNA. The human RNase P gene was detected in the extracted DNA from all colorectal FFPE specimens (mean RNase P gene copy number, $7.9 \times$ $10^{5} \pm 1.3 \times 10^{3}$ copies per microliter; range, $3.9 \times 10^{3}$ to $7.2 \times 10^{6}$ ). The median JCPyV LT-Ag copy number was $64 \times 10^{-2}$ per cell (range, $9.2 \times 10^{-2}$ to $232 \times 10^{-2}$ ) and $14 \times 10^{-2}$ per cell (range, $1 \times 10^{-2}$ to $34 \times 10^{-2}$ ) in the CRC cases and the nonneoplastic inflamed colon mucosa samples, respectively. There was no statistically significant difference between the two study groups regarding the median LT-Ag DNA load ( $p=0.059$ ) (Fig. 1). Since the age of the two groups was different, the association between JCPyV LT-Ag DNA load and CRC was estimated by Bayesian logistic regression analysis, adjusted for age. The OR of the JCPyV LT-Ag DNA load-associated CRC risk was not statistically significant (OR, 2.47; 95\% CI, 0.86-7.12; $p=$ 
0.096). Among the JCPyV-positive samples, the LT-Ag DNA load was higher in 2 metastatic tumors (from a patient with lung metastasis $\left[232 \times 10^{-2}\right.$ copies per cell] and a patient with liver metastasis $\left[121 \times 10^{-2}\right.$ copies per cell] $)$. According to our correlation analysis, there was a significant direct correlation between JCPyV positivity and the moderately and poorly differentiated grades $(r=0.285, p=0.003)$, but this correlation was not significant based on clinicopathologic stage $(r=0.112, p=0.529)$. Additionally, viral load was not statistically significantly correlated with clinicopathologic stage and histological differentiation of the CRC (both $p>0.05$ ).

\section{Discussion}

Polyomaviruses have been studied as probable causes of human cancer since demonstration of the transforming potential of simian virus 40 (SV40). JCPyV is a widespread human polyomavirus with carcinogenic potential which is strongly suspected in tumorigenesis throughout the gastrointestinal tract [14-16, 33-35]. With reference to the possible implication of JCPyV in colorectal tumors via the LT-Ag transforming gene, in the present study we determined the presence of JCPyV LT-Ag sequences in a series of neoplastic and nonneoplastic colorectal samples from Iranian patients. In addition, we evaluated the JCPyV LT-Agpositive samples in terms of viral copy number per cell.

In the current study, JCPyV LT-Ag sequences were detected in $18.6 \%$ of the primary and metastatic CRC tissues and in $15.5 \%$ of the nonneoplastic inflamed colon mucosa samples. According to Table 3, overall, 17 research papers evaluated the presence of JCPyV in CRC patients and controls, and the JCPyV T-antigen was found in 0-86\% of CRC tissues. Compared with most of the previous studies, the present investigation reported a low T-antigen prevalence rate in CRC tissues. Reasons for the lack of agreement in results between these studies include differences in sensitivity of the PCR assays used (conventional PCR, nested PCR, and quantitative real-time PCR), variation in the efficiency of the DNA extraction protocols, possible laboratory contamination, and dissimilarity in patient populations regarding the prevalence of JCPyV infection. The current study used an in-house quantitative real-time PCR technique which was able to detect as few as 50 copies of JCPyV LT-Ag sequences. JCPyV $\mathrm{T}$-antigen sequences were detected in $1.4 \%$ of CRC tissues in a recently published study from Iran [36] using a conventional PCR assay, which is known to have lower sensitivity. To avoid contamination and false-positive results, we used an extraction negative control for each run of DNA extraction, and PCR reaction mixes were prepared in a dedicated clean room under stringent sterile conditions.

Differences in race and lifestyle of a specified population could also contribute to varying rates of JCPyV infection. According to Table 3, most of the previous studies were done on US CRC populations, in which JCPyV genomic sequences were found in $0-81 \%$ of CRC tissues [17, 20, 37, 38]. In addition, inconsistent results have been reported in European, East Asian, and North African populations (Table 3). In the present study, JCPyV genomic sequences were detected in $18.6 \%$ of our Iranian CRC patients. Also, the current study investigated both primary and metastatic CRC tumors, and in contrast to Sinagra et al. [25], our 2 JCPyV-positive metastatic tumors had a negative test result for JCPyV in the corresponding primary CRC. This is a key finding that weakens the hypothesis of an etiological role of JCPyV in primary CRC induction. The present study detected JCPyV genomic sequences in $15.5 \%$ of the nonneoplastic inflamed colon mucosa control samples, a result which is close to that of a recently published report from Tunisia [39]. There was no significant difference in JCPyV positivity between the neoplastic and the nonneoplastic colorectal samples. Apart from age, there was 
Gastro

Intestinal

Tumors
Gastrointest Tumors 2020;7:30-40

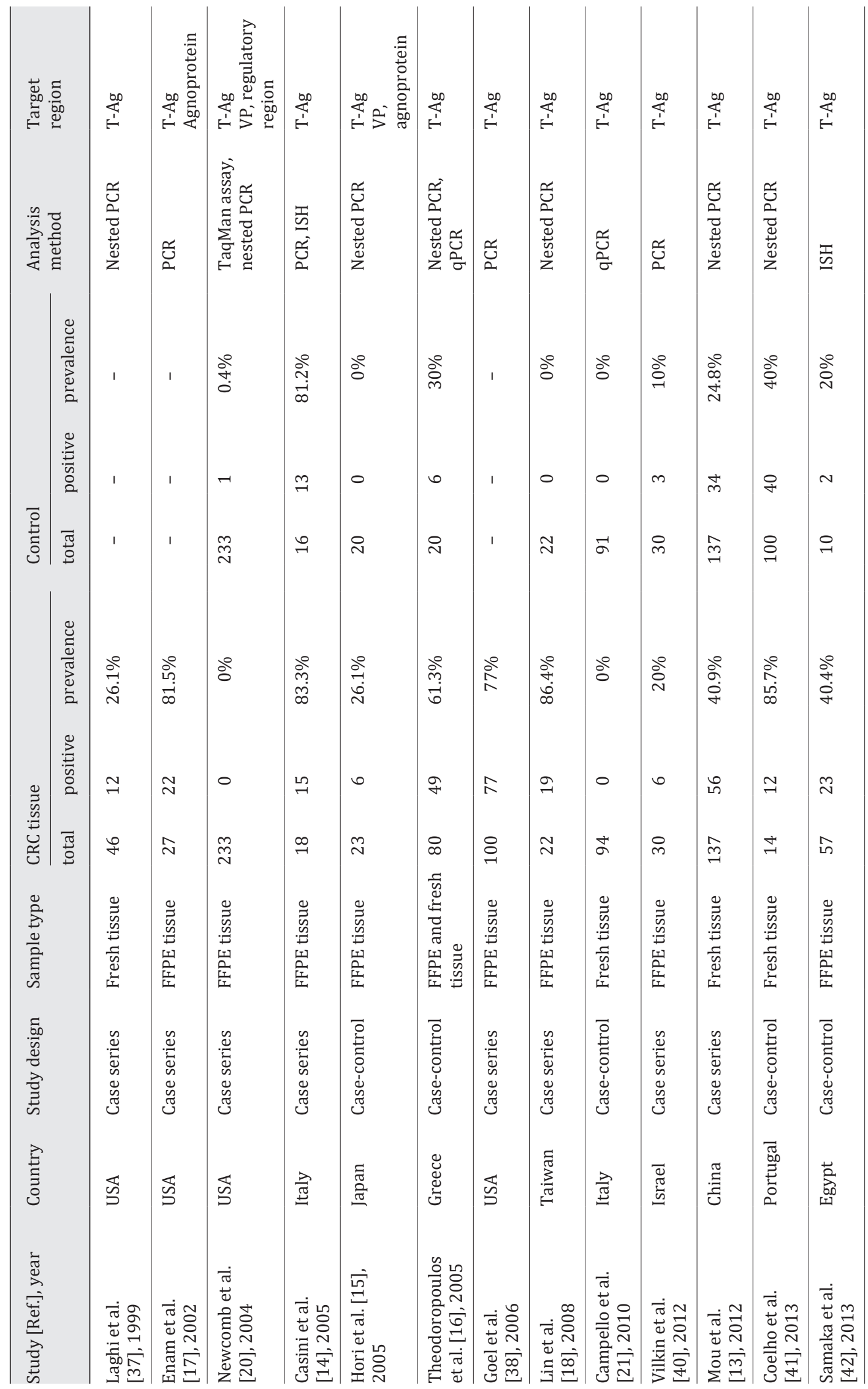


Gastro

Intestinal

Tumors
Gastrointest Tumors 2020;7:30-40

\begin{tabular}{l|l|}
\hline DOI: 10.1159/000504293 & (c) 2019 The Author(s). Published by S. Karger AG, Basel
\end{tabular} www.karger.com/gat

Esmailzadeh et al.: JC Polyomavirus Sequences in Human Colorectal Cancer

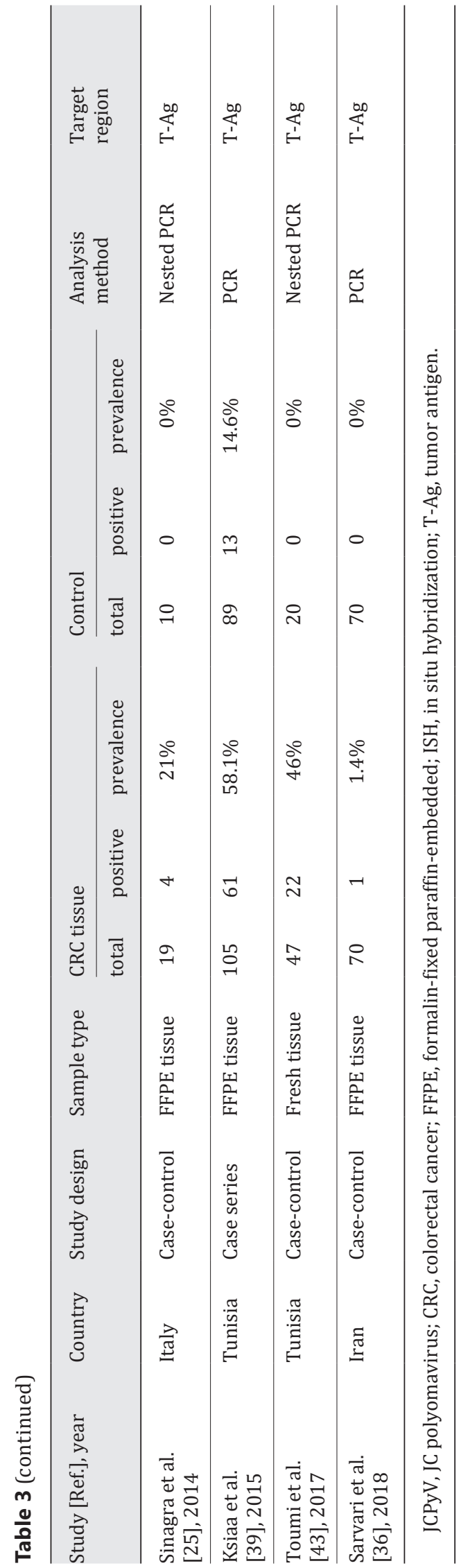


no baseline feature significantly different between the CRC cases and the control group; however, adjustment for age did not change the association between JCPyV infection and CRC.

A high number of viral DNA copies in tissue samples could indicate a possible role of JCPyV in colorectal carcinogenesis. In the current investigation, the JCPyV LT-Ag DNA load was found to be higher among the CRC cases than in the nonneoplastic control group, which is in agreement with previous studies $[13,16,37]$. However, the absolute LT-Ag DNA copy numbers in the tumor tissue were lower than 1 copy per cell. The existence of less than 1 JCPyV LT-Ag DNA copy per cell in neoplastic and nonneoplastic colorectal tissues might be explained by simple persistent viral replication as a passenger virus without any obvious pathological outcome or transient effects of JCPyV on cell transformation by indirect carcinogenic mechanisms like a "hit-and-run" strategy.

Further limitations regarding the current study should be highlighted: (1) due to the FFPE sample set, we were unable to evaluate viral LT-Ag expression on the mRNA level; (2) we lacked p53/pRb SNP and expression data; and (3) there was no healthy colorectal tissue (without inflammation) as a control group.

Taken together, the present study demonstrated the presence of JCPyV LT-Ag sequences at low viral copy numbers (less than 1 viral copy per cell equivalent) in neoplastic and nonneoplastic colorectal samples from Iranian patients. The current study investigated 10 pairs of primary colon adenocarcinomas and their corresponding metastatic specimens, of which only 2 metastatic tumors were JCPyV positive. This is an important finding that weakens the hypothesis of an etiological role of JCPyV in primary CRC induction. Therefore, further worldwide and clear-cut epidemiologic studies should be done to differentiate the possible role of JCPyV in tumor induction from a simple bystander in the development of CRC.

\section{Acknowledgements}

The authors would like to acknowledge the support of the directors and staff at the Pathology Department of Ayatollah Rouhani Hospital affiliated to Babol University of Medical Sciences for their collaboration in sample collection.

\section{Statement of Ethics}

This study was approved by the Ethics Committee of Babol University of Medical Sciences, and for all subjects, written informed consent was obtained.

\section{Disclosure Statement}

The authors declare that they have no conflict of interest.

\section{Author Contributions}

N. Esmailzadeh designed and performed the real-time PCR experiments and cowrote the paper; M. Ranaee provided the samples and performed the pathology experiments; A. Alizadeh performed the statistical analyses; A. Khademian performed the DNA extraction experiments and cowrote the paper; S. Saber Amoli performed the deparaffinization experiments and cowrote the paper; F. Sadeghi supervised the research, designed the experiments, and cowrote the paper. 


\section{References}

1 Bray F, Ferlay J, Soerjomataram I, Siegel RL, Torre LA, Jemal A. Global cancer statistics 2018: GLOBOCAN estimates of incidence and mortality worldwide for 36 cancers in 185 countries. CA Cancer J Clin. 2018 Nov;68(6): 394-424.

2 Johnson CM, Wei C, Ensor JE, Smolenski DJ, Amos CI, Levin B, et al. Meta-analyses of colorectal cancer risk factors. Cancer Causes Control. 2013 Jun;24(6):1207-22.

3 Chen H, Chen XZ, Waterboer T, Castro FA, Brenner H. Viral infections and colorectal cancer: a systematic review of epidemiological studies. Int J Cancer. 2015 Jul;137(1):12-24.

4 Kean JM, Rao S, Wang M, Garcea RL. Seroepidemiology of human polyomaviruses. PLoS Pathog. 2009 Mar; 5(3):e1000363.

5 Monaco MC, Jensen PN, Hou J, Durham LC, Major EO. Detection of JC virus DNA in human tonsil tissue: evidence for site of initial viral infection. J Virol. 1998 Dec;72(12):9918-23.

6 Bofill-Mas S, Formiga-Cruz M, Clemente-Casares P, Calafell F, Girones R. Potential transmission of human polyomaviruses through the gastrointestinal tract after exposure to virions or viral DNA. J Virol. 2001 Nov; 75(21): 10290-9.

7 Ricciardiello L, Laghi L, Ramamirtham P, Chang CL, Chang DK, Randolph AE, et al. JC virus DNA sequences are frequently present in the human upper and lower gastrointestinal tract. Gastroenterology. 2000 Nov;119(5): 1228-35.

8 Bouvard V, Baan RA, Grosse Y, Lauby-Secretan B, El Ghissassi F, Benbrahim-Tallaa L, et al.; WHO International Agency for Research on Cancer Monograph Working Group. Carcinogenicity of malaria and of some polyomaviruses. Lancet Oncol. 2012 Apr;13(4):339-40.

9 Pagano JS, Blaser M, Buendia MA, Damania B, Khalili K, Raab-Traub N, et al. Infectious agents and cancer: criteria for a causal relation. Semin Cancer Biol. 2004 Dec;14(6):453-71.

10 Zur Hausen H. The search for infectious causes of human cancers: where and why. Virology. 2009 Sep; 392(1): 1-10.

11 Delbue S, Comar M, Ferrante P. Review on the role of the human Polyomavirus JC in the development of tumors. Infect Agent Cancer. 2017 Feb;12(1):10.

12 Ricciardiello L, Baglioni M, Giovannini C, Pariali M, Cenacchi G, Ripalti A, et al. Induction of chromosomal instability in colonic cells by the human polyomavirus JC virus. Cancer Res. 2003 Nov;63(21):7256-62.

13 Mou X, Chen L, Liu F, Lin J, Diao P, Wang H, et al. Prevalence of JC virus in Chinese patients with colorectal cancer. PLoS One. 2012;7(5):e35900.

14 Casini B, Borgese L, Del Nonno F, Galati G, Izzo L, Caputo M, et al. Presence and incidence of DNA sequences of human polyomaviruses BKV and JCV in colorectal tumor tissues. Anticancer Res. 2005 Mar-Apr;25(2A):107985.

15 Hori R, Murai Y, Tsuneyama K, Abdel-Aziz HO, Nomoto K, Takahashi H, et al. Detection of JC virus DNA sequences in colorectal cancers in Japan. Virchows Arch. 2005 Oct;447(4):723-30.

16 Theodoropoulos G, Panoussopoulos D, Papaconstantinou I, Gazouli M, Perdiki M, Bramis J, et al. Assessment of JC polyoma virus in colon neoplasms. Dis Colon Rectum. 2005 Jan;48(1):86-91.

17 Enam S, Del Valle L, Lara C, Gan DD, Ortiz-Hidalgo C, Palazzo JP, et al. Association of human polyomavirus JCV with colon cancer: evidence for interaction of viral T-antigen and beta-catenin. Cancer Res. 2002 Dec;62(23): 7093-101.

18 Lin PY, Fung CY, Chang FP, Huang WS, Chen WC, Wang JY, et al. Prevalence and genotype identification of human JC virus in colon cancer in Taiwan. J Med Virol. 2008 Oct;80(10):1828-34.

19 Hernández Losa J, Fernandez-Soria V, Parada C, Sanchez-Prieto R, Ramón Y Cajal S, Fedele CG, et al. JC virus and human colon carcinoma: an intriguing and inconclusive association. Gastroenterology. 2003 Jan;124(1): 268-9; author reply 269-70.

20 Newcomb PA, Bush AC, Stoner GL, Lampe JW, Potter JD, Bigler J. No evidence of an association of JC virus and colon neoplasia. Cancer Epidemiol Biomarkers Prev. 2004 Apr;13(4):662-6.

21 Campello C, Comar M, Zanotta N, Minicozzi A, Rodella L, Poli A. Detection of SV40 in colon cancer: a molecular case-control study from northeast Italy. J Med Virol. 2010 Jul;82(7):1197-200.

22 Behren A, Simon C, Schwab RM, Loetzsch E, Brodbeck S, Huber E, et al. Papillomavirus E2 protein induces expression of the matrix metalloproteinase- 9 via the extracellular signal-regulated kinase/activator protein-1 signaling pathway. Cancer Res. 2005 Dec;65(24):11613-21.

23 Gou XM, Chen Y, Chen XY, Arrand JR. Effects of Epstein-Barr virus latent membrane protein 1 (EBV-LMP1) on related factors of metastasis of nasopharyngeal carcinoma cell line CNE1 [in Chinese]. Ai Zheng. 2003 May; 22(5):481-5.

24 Link A, Shin SK, Nagasaka T, Balaguer F, Koi M, Jung B, et al. JC virus mediates invasion and migration in colorectal metastasis. PLoS One. 2009 Dec;4(12):e8146.

25 Sinagra E, Raimondo D, Gallo E, Stella M, Cottone M, Orlando A, et al. Could JC virus provoke metastasis in colon cancer? World J Gastroenterol. 2014 Nov;20(42):15745-9.

26 Rollison DE. JC virus infection: a cause of colorectal cancer? J Clin Gastroenterol. 2010 Aug;44(7):466-8.

27 Yahyapour Y, Sadeghi F, Alizadeh A, Rajabnia R, Siadati S. Detection of Merkel Cell Polyomavirus and Human Papillomavirus in Esophageal Squamous Cell Carcinomas and Non-Cancerous Esophageal Samples in Northern Iran. Pathol Oncol Res. 2016 Oct;22(4):667-72. 
28 Yahyapour Y, Shamsi-Shahrabadi M, Mahmoudi M, Siadati S, Shahryar SS, Shokri-Shirvani J, et al. Evaluation of human papilloma virus infection in patients with esophageal squamous cell carcinoma from the Caspian Sea area, north of Iran. Asian Pac J Cancer Prev. 2012;13(4):1261-6.

29 Yazdani Cherati A, Yahyapour Y, Ranaee M, Rajabnia M, Shokri Shirvani J, Hajiahmadi M, et al. No Evidence for an Association between JC Polyomavirus Infection and Gastroduodenal Diseases. Gastrointest Tumors. 2018 Sep;5(1-2):47-53.

30 Sadeghi F, Salehi-Vaziri M, Ghodsi SM, Alizadeh A, Bokharaei-Salim F, Saroukalaei ST, et al. Prevalence of JC polyomavirus large $\mathrm{T}$ antigen sequences among Iranian patients with central nervous system tumors. Arch Virol. 2015 Jan;160(1):61-8.

31 MacKenzie J, Wilson KS, Perry J, Gallagher A, Jarrett RF. Association between simian virus 40 DNA and lymphoma in the United Kingdom. J Natl Cancer Inst. 2003 Jul;95(13):1001-3.

32 Imajoh M, Hashida Y, Taniguchi A, Kamioka M, Daibata M. Novel human polyomaviruses, Merkel cell polyomavirus and human polyomavirus 9, in Japanese chronic lymphocytic leukemia cases. J Hematol Oncol. 2012 Jun; $5(1): 25$.

33 Del Valle L, White MK, Enam S, Piña Oviedo S, Bromer MQ, Thomas RM, et al. Detection of JC virus DNA sequences and expression of viral $\mathrm{T}$ antigen and agnoprotein in esophageal carcinoma. Cancer. 2005 Feb; 103(3):516-27.

34 Shin SK, Li MS, Fuerst F, Hotchkiss E, Meyer R, Kim IT, et al. Oncogenic T-antigen of JC virus is present frequently in human gastric cancers. Cancer. 2006 Aug;107(3):481-8.

35 Ksiaa F, Ziadi S, Mokni M, Korbi S, Trimeche M. The presence of JC virus in gastric carcinomas correlates with patient's age, intestinal histological type and aberrant methylation of tumor suppressor genes. Mod Pathol. 2010 Apr;23(4):522-30.

36 Sarvari J, Mahmoudvand S, Pirbonyeh N, Safaei A, Hosseini SY. The Very Low Frequency of Epstein-Barr JC and BK Viruses DNA in Colorectal Cancer Tissues in Shiraz, Southwest Iran. Pol J Microbiol. 2018 Mar;67(1):73-9.

37 Laghi L, Randolph AE, Chauhan DP, Marra G, Major EO, Neel JV, et al. JC virus DNA is present in the mucosa of the human colon and in colorectal cancers. Proc Natl Acad Sci USA. 1999 Jun; 96(13):7484-9.

38 Goel A, Li MS, Nagasaka T, Shin SK, Fuerst F, Ricciardiello L, et al. Association of JC virus T-antigen expression with the methylator phenotype in sporadic colorectal cancers. Gastroenterology. 2006 Jun;130(7):1950-61.

39 Ksiaa F, Allous A, Ziadi S, Mokni M, Trimeche M. Assessment and biological significance of JC polyomavirus in colorectal cancer in Tunisia. J BUON. 2015 May-Jun;20(3):762-9.

40 Vilkin A, Ronen Z, Levi Z, Morgenstern S, Halpern M, Niv Y. Presence of JC virus DNA in the tumor tissue and normal mucosa of patients with sporadic colorectal cancer (CRC) or with positive family history and Bethesda criteria. Dig Dis Sci. 2012 Jan;57(1):79-84.

41 Coelho TR, Gaspar R, Figueiredo P, Mendonça C, Lazo PA, Almeida L. Human JC polyomavirus in normal colorectal mucosa, hyperplastic polyps, sporadic adenomas, and adenocarcinomas in Portugal. J Med Virol. 2013 Dec;85(12):2119-27.

42 Samaka RM, Abd El-Wahed MM, Aiad HA, Kandil MA, Al-Sharaky DR. Does JC virus have a role in the etiology and prognosis of Egyptian colorectal carcinoma? APMIS. 2013 Apr;121(4):316-28.

43 Toumi W, Ripalti A, Ricciardiello L, Cherif A, Gargouri D, Bouhafa A, et al. Detection of a new JCV strain of genotype A in a subpopulation of colorectal adenocarcinomas in Tunisia. New Microbiol. 2017 Apr;40(2): 99-106. 